\title{
Defence expenditure and economic growth in Latin American countries: evidence from linear and nonlinear causality tests
}

\author{
Christos Kollias $^{1} \cdot$ Suzanna-Maria Paleologou ${ }^{2}$ • \\ Panayiotis Tzeremes ${ }^{1} \cdot$ Nickolaos Tzeremes $^{1}$
}

Received: 29 May 2016/Revised: 21 January 2017/ Accepted: 27 January 2017 /

Published online: 9 February 2017

(C) The Author(s) 2017. This article is published with open access at Springerlink.com

\begin{abstract}
Using SIPRI's new consistent database on military expenditures, the paper examines the economic effects of such spending in the case of the 13 Latin American countries. Employing both linear and nonlinear tests, the nexus between defence spending, economic growth, and investment is investigated for the period 1961-2014. Findings reported herein are not uniformed across all countries included in the sample. However, as a broad tentative generalization, they seem to be pointing to the absence of a strong and robust nexus between the variables examined.
\end{abstract}

Keywords Latin America · Military spending · Growth · Causality

JEL Classification $\mathrm{H} 56 \cdot \mathrm{C} 22 \cdot \mathrm{O} 54$

\section{Introduction}

The empirical assessment of the economic effects of military spending is a contentious theme that has attracted considerable attention and debate without, however, the emergence of a robust and unequivocal consensus (inter alia: Alptekin and Levine 2012; Dunne and Tian 2013; Dunne and Smith 2010; Heo and Ye 2016). Essentially, the effects of such government outlays can be summarized into three broad categories: the opportunity cost of the resources allocated to national defence, encapsulated by the guns vs butter dilemma; demand stimulation; and supply side effects (inter alia: Drèze 2006; Dunne and Tian 2016; Dunne and Uye 2010; Hou

Christos Kollias

kollias@uth.gr

1 University of Thessaly, Volos, Greece

2 Aristotle Univesrity of Thessaloniki, Thessaloniki, Greece 
and Chen 2013; Desli et al. 2016). The growth enhancing effects include increased employment of idle or underemployed resources, positive externalities, such as technological advances, that spillover to other sectors of the economy thus increasing productivity, infrastructure creation, and human capital formation. On the other hand, such spending can prove to be growth retarding through the crowding-out of other more productive forms of public spending as well as investment. Both cross-country and specific country case studies have empirically probed into this question with mixed findings, as noted above, although the scales do seem to tilt in favor of a negative net impact on growth (inter alia: Compton and Paterson 2016; Malizard 2015, 2016; Dunne and Tian 2015, 2016; Kollias and Paleologou 2016).

The issue of the economic impact of military spending has also been addressed for Latin American countries. Ramos (2004) finds a positive effect on growth in the case of Mexico. For Guatemala, Reitschuler and Loening (2005) report findings that point to a positive and significant externality effect of defence spending at low levels of such expenditure but not so for higher levels. Using a sample of Asian and Latin American countries, Murdoch et al. (1997) find that defence is growth promoting but generates an opportunity cost in the form of displacing other public expenditures that also boost growth. Stroup and Heckelman (2001) for a group of African and Latin American countries establish a nonlinear relationship between defence and growth, with the findings indicating that low levels of such expenditure increase economic growth, whereas high levels decrease it. Scheetz (1991), in the case of Argentina, Chile, Paraguay, and Peru, reports a negative effect on macroeconomic variables, such as growth, investment, and the current account balance. Klein (2004) also reports a negative net effect in the case of Peru over the period 1970-1996.

Hoping to contribute to the existing body of literature for Latin America by extending both the time period as well as the sample of countries, this paper (re)addresses the issue of the economic effects of defence expenditure using SIPRI's ${ }^{1}$ new database (Perlo-Freeman and Sköns 2016; Smith 2016). SIPRI has recently extended its military expenditure data set that until now provided consistent data only from 1988 onwards. The new data set $^{2}$ has consistent defence spending estimates across countries that in a number of cases date back to 1949 . Hence, it presents researchers with the opportunity to readdress the perennial question of the economic effects of military expenditure, since it allows to empirically probe into this issue for an appreciably longer time period compared to the previous studies. In the case of the Latin American countries, this implies the addition of more than 20 years in the sample period. There are obvious advantages associated with the availability of consistent and reliable time series with observations that cover longer periods. They offer the opportunity for researchers to reach more robust and reliable inferences over a longer time horizon that, in this case, spans both the bipolar and post-bipolar periods. Hence, better insights may be gained when it comes to the empirical appraisal of the economic effects of military spending. This paper, using

\footnotetext{
${ }^{1}$ Stockholm International Peace Research Institute.

${ }^{2}$ Before its official public release, this dataset was made available to a number of researchers to use and evaluate.
} 
both linear and nonlinear causality tests, examines the economic effects of defence spending in the case of the 13 Latin American countries. The tests cover the period 1961-2014. The structure of the paper is as follows. The next section contains a descriptive comparative presentation of the data used, while Section 3 epigrammatically addresses the role of the military in Latin America from a comparative perspective in terms of defence burdens and economic performance. In Section 4, the methodology employed is briefly outlined and the findings are presented and discussed in Section 5. Finally, Section 6 concludes the paper.

\section{Sample and data snapshots}

Dictated solely by data availability, the 13 Latin American countries are included in the sample: Dominican Republic, El Salvador, Guatemala, Mexico, Argentina, Bolivia, Brazil, Chile, Colombia, Ecuador, Paraguay, Peru, and Venezuela. As already pointed out, the military expenditure data is drawn from SIPRI's new consistent database. In line with the standard practice in the relevant literature, the defence burden, i.e., defence spending expressed as a share of GDP, is used in the empirical analysis that follows. The GDP growth rates and gross capital formation expressed as a share of GDP are drawn from the World Bank's World Development Indicators' database. The time period covered is $1961-2014 .^{3}$ In Table 1 , the mean values of the three variables are presented for each country in the sample both for the entire period (1961-2014) as well as for sub-periods. Starting from the overall growth performance, it is the Dominican Republic that exhibits the highest average growth rate for the entire period (5.29\%) followed by Paraguay (4.89\%). Noteworthy is the fact that the mean growth rates of a number of other countries are above $4 \%$ for the whole period-Mexico (4.08\%), Brazil (4.39\%), Chile (4.3\%), and Ecuador (4.07\%) - with El Salvador, Venezuela, and Argentina having the lowest averages of the group: $2.38,2.8$, and $2.9 \%$, respectively. Not surprisingly, significant variations in terms of growth performance are recorded from one decade to the other for all the 13 countries. Worth mentioning, however, is that compared to the world economy, all the 13 countries have over-performed in terms of growth rates. The global average growth rate for the entire period was around $1.9 \%$ according to the World Bank data. The 13 Latin American countries of the sample had mean growth rates that in cases were higher by more than $2 \%$ points compared to the world's average and 3\% points in the case of Paraguay and the Dominican Republic (Fig. 1). In terms of gross capital formation expressed as a percentage of GDP, Guatemala, El Salvador, and Bolivia are the three with the lowest averages for the entire period-15.3, 15.9, and $15.9 \%$, respectively, followed by Paraguay with an average of $17.5 \%$ (Table 1 ).

We now turn to present briefly the defence burdens of the 13 Latin American countries both in terms of the averages recorded over the period in question, as well as in terms of how this variable has fluctuated in the sub-periods, as presented in

\footnotetext{
${ }^{3}$ With the exception of El Salvador where the tests are conducted for 1965-2014 and Bolivia with the estimations covering the period 1968-2014 due to data availability constraints.
} 


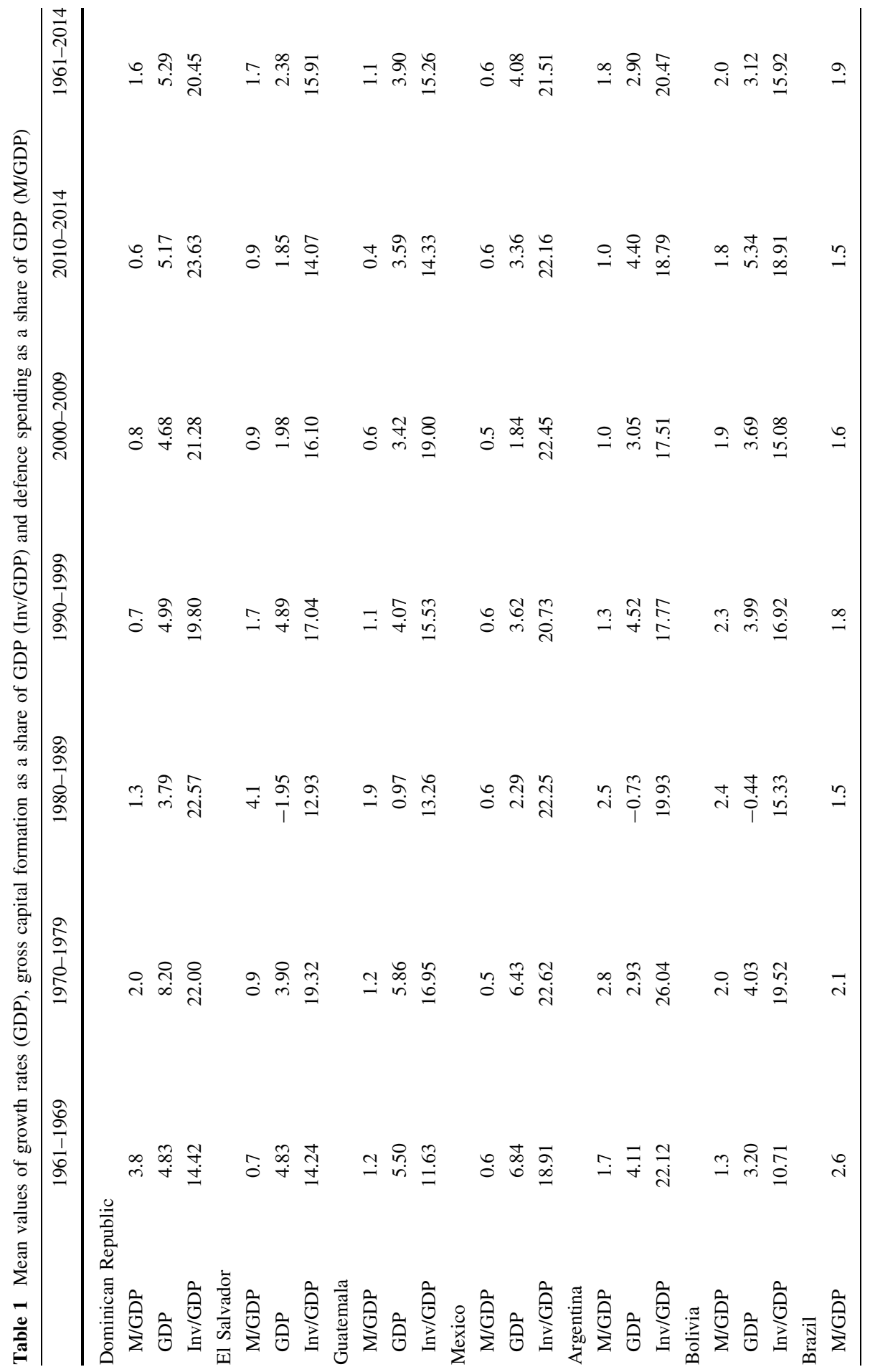




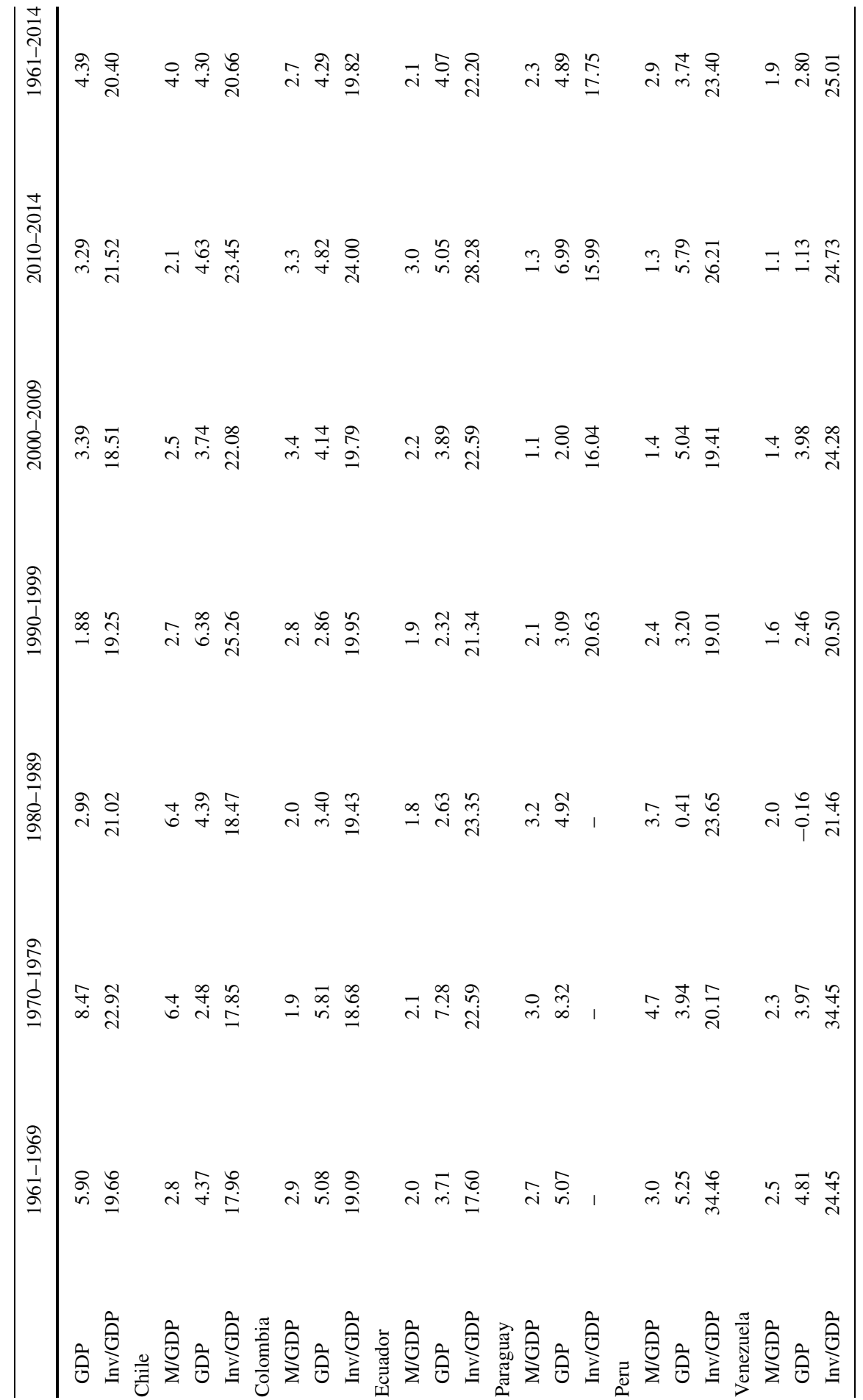




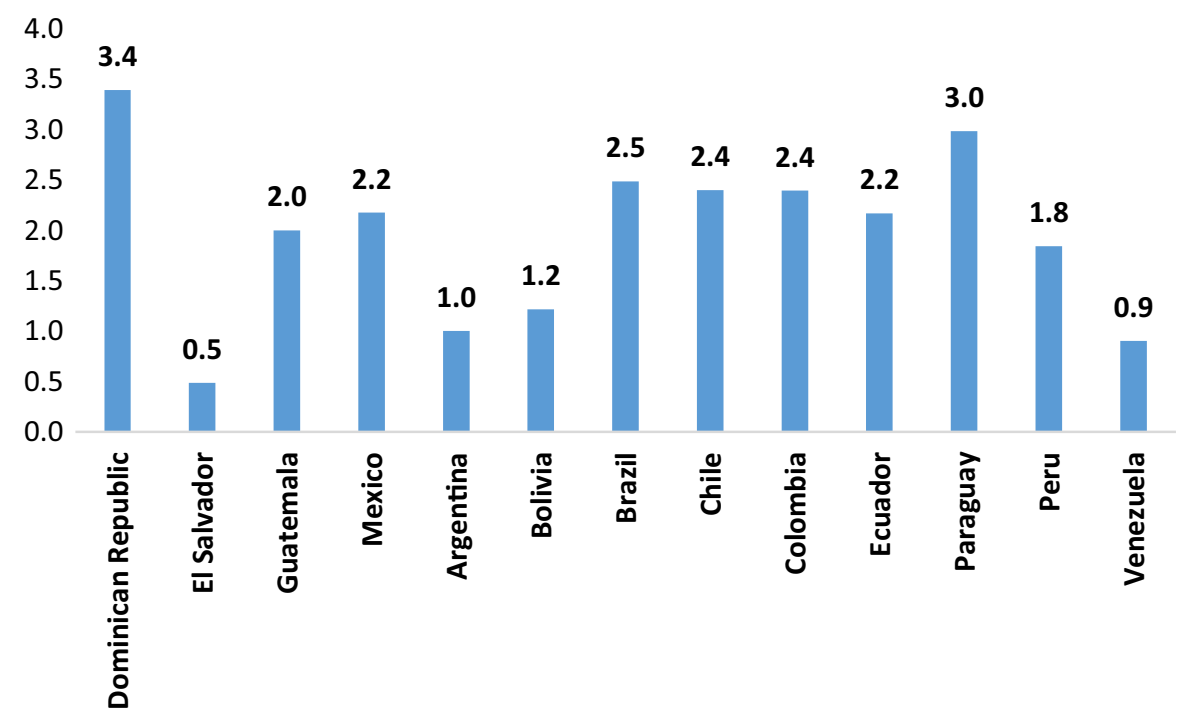

Fig. 1 Growth over-performance vis-à-vis the world average 1961-2014 (Growth rate of the $i$ th country minus the world average)

Table 1. The annual defence budget is the monetary quantification of the resources allocated to national defence and denotes the costs of the inputs that go into the production of military capabilities. As suggested in the relevant literature, cohort of factors determines the level of the resources allocated to the military including external as well as domestic security considerations, economic constraints, strategic aspirations, and the ideological and political orientation of the incumbent government (inter alia: Bove and Brauner 2016; Wang 2013; Dunne et al. 2008). Expressed as a share of GDP, military expenditure reflects the defence burden of a country in terms of the inputs that the implementation of national defence policy absorbs. As a first broad observation in terms of the 1961-2014 averages, it can be seen that Mexico has the lowest mean value in terms of military spending as a share of GDP over the entire period $(0.6 \%)$. Noteworthy, is that the value of Mexican defence burden has more or less remained constant over the sub-period presented in the table. The country with the highest average is Chile (4\%). Interesting to observe is that the Chilean defence burden was as high as 6.4\% during 1970-1989 and this probably can be associated with the Chilean junta (1973-1990). For example, in 1982, military spending as a share of GDP in Chile reached 8.9\%. Following the collapse of the regime, it dropped appreciably in the next decades (Table 1). Peru and Colombia are the next two countries with the highest defence burden: 2.9 and $2.7 \%$, respectively. Although the empirical investigation of the determinants of such expenditures falls outside the scope of this paper, in the case of Peru, the longrunning territorial disputes with Ecuador as well as domestic security issues associated with terrorist activity by Sendero Luminoso and the Tupac Amaru Revolutionary Movement (Klein 2004). Similarly, internal strife and conflict in 


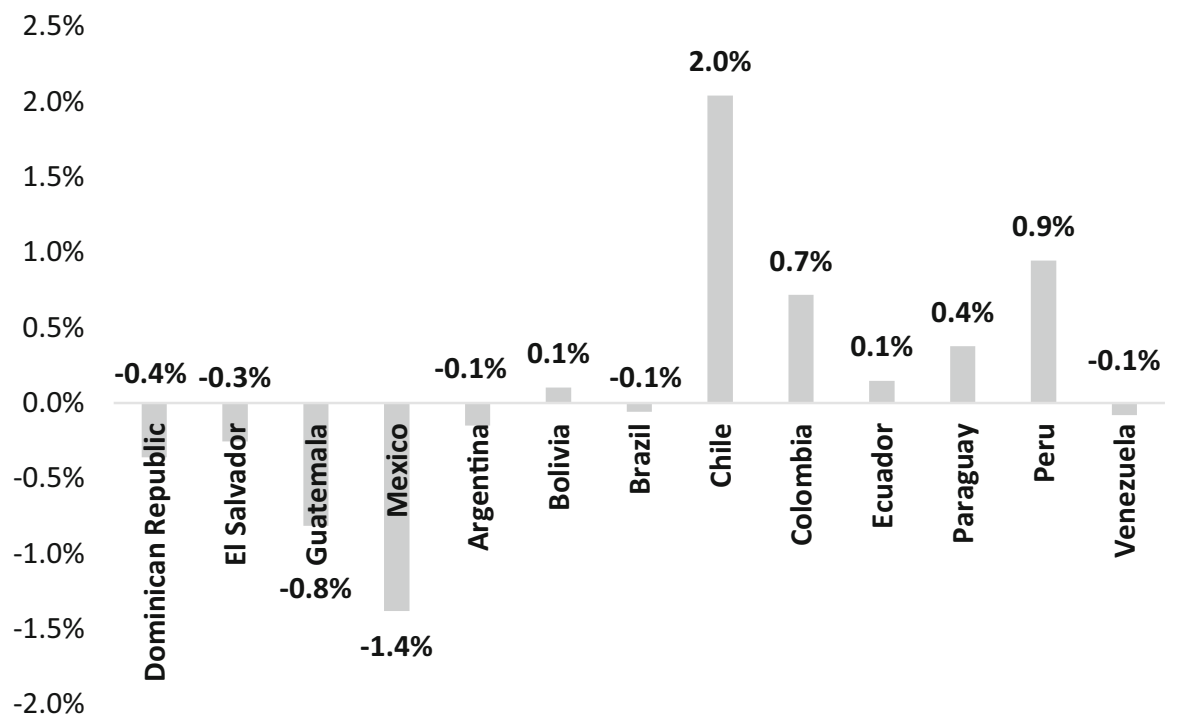

Fig. 2 Defence burden of Latin American countries compared to the world average 1961-2014 (Defence burden of the $i$ th country minus the world average)

Colombia between government forces, paramilitaries, insurgents, such as FARC, and crime syndicates, can be cited as explanatory factors of comparatively higher defence spending (Vargas 2012). However, the overall assessment of the 13 Latin American countries included in our sample is that in comparative terms, their defence burden in most cases has been lower than the world average during the period in question (Fig. 2).

\section{The military in Latin America: a bird's eye view of defence burdens and growth}

A particular feature of Latin American countries is the role that the armed forces have played in domestic politics (inter alia: Catoggio 2011; Frantz and Geddes 2016; Biglaiser 2002). For reasons of brevity, we focus exclusively on the time period of our sample and the countries included in it. During 1961-2014, out of the 13 countries of the sample less than a handful-Mexico, ${ }^{4}$ Colombia, Venezuela, and the Dominican Republic ${ }^{5}$ - were not directly ruled by a military government. In fact, the direct or indirect involvement of the military in the political scene of almost all Latin American countries was for decades an endemic feature of the region and its legacy has left an indelible imprint in Latin American history. However, as many have pointed out, the dominant presence and central role of the military in Latin

\footnotetext{
4 The only country out of the thirteen contained in the sample that has enjoyed uninterrupted parliamentary rule since the early twentieth century.

5 The Trujillo Era in the Dominican Republic ended with his assassination in 1961.
} 
Table 2 GDP growth rates and defence spending as a share of GDP during military rule in selected Latin American countries

\begin{tabular}{lll}
\hline & M/GDP\% & GDP\% \\
\hline Brazil 1964-1985 & 2 & 6.2 \\
Sample's average 1964-1985 & 2.5 & 4.1 \\
Country's average 1961-2014 & 1.9 & 4.4 \\
Chile 1973-1990 & 6.3 & 3.4 \\
Sample's average 1973-1990 & 2.5 & 3.1 \\
Country's average 1961-2014 & 4 & 4.3 \\
Argentina 1966-1973 & 1.7 & 3.8 \\
Sample's average 1966-1973 & 2.2 & 5.5 \\
Argentina 1976-1983 & 3.6 & 1 \\
Sample's average 1976-1983 & 2.6 & 2.7 \\
Country's average 1961-2014 & 1.8 & 2.9 \\
Peru 1968-1980 & 4.4 & 3.8 \\
Sample's average 1968-1980 & 2.4 & 5.2 \\
Country's average 1961-2014 & 2.9 & 3.7 \\
Bolivia 1970-1982 & 2.3 & 2.7 \\
Sample's average 1970-1982 & 2.5 & 4.5 \\
Country's average 1961-2014 & 2 & 3.1 \\
\hline
\end{tabular}

American politics, either in the form of direct military rule or military coups, rapidly withered away towards the late 1980s (inter alia: Norden 1996; Dix 1994). Even though a plethora of themes related to the role of the military in Latin American countries could be addressed, we opt to focus onto two of the key variables examined herein: the defence burden and GDP growth rate in the case of six periods of direct military rule in five selected countries: Brazil, Chile, Argentina, Peru, and Bolivia. All five have experienced direct military rule during the period examined here. Following the 1964 coup, Brazil was ruled by a military government until 1985. Chile between 1973 and 1990 following the overthrow of Salvador Allende's government, Peru 1968-1980, and Bolivia when between 1970 and 1982 were also ruled by successive military juntas. With the exception of a brief spell, Argentina was also under direct military rule between 1966-1973 and 1976-1983 when the military government collapsed following the 1982 military defeat by the United Kingdom.

In Table 2, we present the following statistics for comparison purposes: the average defence burden (M/GDP) and GDP growth rate during the period of military rule in the aforementioned countries; the corresponding averages of these variables for the entire sample of the 13 countries during the same period and the country's average defence burden and growth rate for the entire sample period, i.e., 1961-2014. Thus, we allow for comparisons on two levels. First, on how the country faired in terms of these two variables vis-à-vis the entire sample during each period of direct military rule, and second, how the military rule period compares with the country's averages over the entire period. Starting from the defence burden level, it appears that in most cases, spending on defence expressed as a share of 
GDP was higher during military rule compared to the country's average for the entire period. This is the case for Chile (1973-1990), Argentina (1976-1983), and Peru (1968-1980) but less so for Brazil (1964-1985), Argentina (1966-1973), and Bolivia (1970-1982) in which cases, the defence burden during military government is not appreciably higher than the average of the entire period examined here. To put things into perspective, a comparison with the sample's average defence burden during each period of military rule yields a similar picture. In the cases of Chile (1973-1990), Argentina (1976-1983), and Peru (1968-1980), military spending expressed as a percentage of GDP is noticeably higher than the sample's average during the same period: $6.3 \%$ vs a sample average of $2.5 \%$ in the case of Chile (1973-1990), 3.6 vs $2.6 \%$ in the case of Argentina (1976-1983), and 4.4\% vs a sample average of $2.5 \%$ in the case of Peru (1968-1980). Noteworthy is the fact that in the case of Brazil (1964-1985), Argentina (1966-1973), and Bolivia (1970-1982), their defence burdens during military rule were lower than the sample's average for the same periods (2 vs $2.5 \%, 1.7$ vs $2.2 \%$, and 2.3 vs $2.5 \%$, respectively). Although such descriptive analysis falls short from offering robust inferences than a more systematic empirical investigation would, it nevertheless coincides with the findings of other studies that have addressed the determinants of defence budgets in Latin America (inter alia: Looney and Frederiksen 2000, 1988; Peláez 2007). A similarly mixed picture emerges if we compare growth performance during military rule (Table 2). For example, Brazil's growth rate under military government was noticeably higher than the sample's average during the same period (1964-1985) - 6.2 vs $4.1 \%$ - as well as higher than its average (4.4\%) over the entire period examined here. Exactly the reverse is the case for Argentina (1976-1983). The sample's average growth rate during the same period was more than double (2.7 vs $1 \%$ ) and so was its average over the whole sample period (2.9 vs $1 \%$ ). A more diverse picture emerges for the other cases presented in Table 2. For example, Argentina (1966-1973) significantly underperforms vis-à-vis the sample's average for the same period (3.8 vs 5.5\%) but has a higher growth rate compared to the one of the entire period. A considerable underperformance compared to the sample's average growth rate for the same period is also the case for Peru (1968-1980) - 3.8 vs 5.2\% — and also for Bolivia (1970-1982) - 2.7 vs $4.5 \%$. Chile's growth rate during the dictatorship (1973-1990) was roughly the same to that of the sample for the same period (3.4 vs 3.1\%). On balance, it appears that for most of the selected countries shown in Table 2, growth underperformance vis-à-vis the sample for the same period is the case during military rule.

\section{Methodology: a brief outline}

As noted earlier, to examine the economic effects of defence spending in the case of the 13 Latin American countries of our sample, both linear and nonlinear causality tests will be employed. For the linear causality, we apply the Granger-causality test following the Toda and Yamamoto (1995) (hereafter TY). Following Granger's (1969) development of the causality test, two shortcomings were identified. One relates to the specification bias and the other to the presence of spurious regression. As 
explained by Engel and Granger (1987), two series are regarded to be cointegrated if the linear combination of these two series is stationary, however, every variable is not. As a result, they stressed that when these two series are non-stationary and cointegrated, the Granger-causal inference will be biased. In addition, in the asymptotic distribution framework, Sims et al. (1990) have produced evidence that when applying the vector autoregressive (VAR) model, we cannot test for the causality of integrated variables in level form regardless if these variables are cointegrated. However, the TY applied in this study overcomes those problems, since it is based on augmented VAR modeling having a modified Wald test statistic (MWALD), which asymptotically as a Chi-square distribution. Moreover, since the test used here (i.e., TY) does not require any pre-tests for cointegration, it presents a better alternative over the traditional Granger-causality test. As Toda and Yamamoto (1995) explain, their test can be applied regardless of whether a series is I(0), I(1), or I(2), non-cointegrated or cointegrated of an arbitrary order producing valid estimates. This is quite suitable in our case, since the economies examined herein reveal several structural breaks ${ }^{6}$ in the macroeconomic variables used. Finally, as Kuzozumi and Yamamoto (2000) suggest, the TY test should be preferred when sample sizes are small, since the distortions of the small sample properties remain in low levels, given the potential bias related to the asymptotic distribution of the applied test.

The approach developed by TY employs a modified Wald test for restriction on the parameters of the $\operatorname{VAR}(k)$, where $k$ is the lag length of the model. The TY test is to artificially augment the correct order, $k$, by the maximal order of integration, say $d_{\text {max }}$. Once this is done, a $\left(k+d_{\max }\right)$ th order of VAR is measured and the coefficients of the last lagged $d_{\max }$ vectors are ignored (Menyah and Wolde-Rufael 2010). ${ }^{7}$ Following this approach, the military expenditure (MGDP) and economic growth (GDP) model is given in the following VAR system:

$$
\begin{aligned}
\ln \mathrm{MGDP}_{t}= & a_{o}+\sum_{i=1}^{k} a_{1 i} \ln \mathrm{MGDP}_{t-i}+\sum_{j=k+1}^{d \max } a_{2 i} \ln \mathrm{MGDP}_{t-j}+\sum_{i=1}^{k} \beta_{1 i} \ln \mathrm{GDP}_{t-i}+ \\
& \times \sum_{j=k+1}^{d \max } \beta_{2 i} \ln \mathrm{GDP}_{t-j}+\sum_{i=1}^{k} \gamma_{1 i} \ln \mathrm{INV}_{t-i}+\sum_{j=k+1}^{d \max } \gamma_{2 i} \ln \mathrm{INV}_{t-j}+\varepsilon_{1 t}
\end{aligned}
$$

$$
\begin{aligned}
\ln \mathrm{GDP}_{t}= & \vartheta_{o}+\sum_{i=1}^{k} \vartheta_{1 i} \ln \mathrm{MGDP}_{t-i}+\sum_{j=k+1}^{d \max } \vartheta_{2 i} \ln \mathrm{MGDP}_{t-j}+\sum_{i=1}^{k} \lambda_{1 i} \ln \mathrm{GDP}_{t-i} \\
& +\sum_{j=k+1}^{d \max } \lambda_{2 i} \ln \mathrm{GDP}_{t-j}+\sum_{i=1}^{k} v_{1 i} \ln \mathrm{INV}_{t-i}+\sum_{j=k+1}^{d \max } v_{2 i} \ln \mathrm{INV}_{t-j}+\varepsilon_{2 t}
\end{aligned}
$$

\footnotetext{
6 For the identification of multiple breaks see Kapetanios (Kapetanios 2005).

7 For more details see Toda and Yamamoto (1995) or for shortcoming see, Caporale and Pittis (1999) and Wolde-Rufael (2004, 2005, 2006).
} 
where $\ln \mathrm{MGDP}_{t}$ represents countries' military spending as a share of GDP, $\ln \mathrm{GDP}_{t}$ countries' annual growth rate of GDP, and $\ln \mathrm{INV}_{t}$ countries' gross fixed capital formation as of GDP. ${ }^{8}$ Support of the growth-enchasing hypothesis suggests a unidirectional Granger causality running from military expenditure (MGDP) measure to the annual growth rate of GDP $\left(\vartheta_{1 i} \neq 0 \forall_{i}\right)$. When we have the presence of unidirectional Granger causality running from the annual growth rate of GDP to the military expenditure $\left(\beta_{1 i} \neq 0 \forall_{i}\right)$, it is evident that the conservation hypothesis holds. On the other hand, when the feedback hypothesis is true, it suggests the existence of a bidirectional Granger causality between both variables, i.e., military expenditure and the annual growth rate $\left(\beta_{1 i} \neq 0 \forall_{i}\right)$ and $\left(\vartheta_{1 i} \neq 0 \forall_{i}\right)$. Finally, the absence of Granger causality between the MGDP and the growth rate $\left(\beta_{1 i}=0 \forall_{i}\right)$ and $\left(\vartheta_{1 i}=0 \forall_{i}\right)$ implies the existence of the impartiality hypothesis. Moreover, to overcome the bias of the omitted variable in growth models, a multivariate framework is applied by incorporating the measures of gross fixed capital formation in addition to military expenditure and GDP. ${ }^{9}$ Before we estimate our model and proceed with the TY test, we apply several diagnostic tests (normality, serial correlation, heteroscedasticity, and the CUSUM and CUSUM of square tests) and we resort to the use of four unit roots tests to explore the degree of integration of the variables used in the empirical analysis. Namely, we apply the Augmented Dickey and Fuller (1979) (ADF) test, the Phillips and Perron (1988) (PP) test, the Kwiatkowski et al. (1992) (KPSS) test, and the Zivot and Andrews (1992) test. Finally, although tTY suggest that cointegration is not required in order for the estimates to be valid, we apply the Johansen and Juselius (1990) test as robustness check. ${ }^{10}$

As Brock (1991) illustrates, linear Granger-causality tests can have low power uncovering nonlinear causal relations, which could also exist among variables. In addition, the assumption of linear causality may act as a limiting factor when the true relationship could be nonlinear. Furthermore, since linear methods depend on testing the significance of suitable parameters only in a mean equation, causality in any higher order structure cannot be explored Diks and DeGoede (2001). For that reasons, we examine the nonlinear non-Granger causality. Baek and Brock (1992), to emphasize the limitations of the linear assumption, suggest a nonparametric statistical method for detecting nonlinear Granger causality. Whereas, Hiemstra and Jones (1994) extended their work by introducing a modified test statistic for the nonlinear causality. In addition, Diks and Panchenko (2006) (hereafter DP) develop a new nonparametric test statistic for Granger causality which enable us to avoid the problem of over-rejection observed in the frequently used test proposed by Hiemstra and Jones. As a result, in our paper, we apply the nonlinear causality test proposed by Diks and Panchenko (2006) which can be used to detect possible nonlinear causality relationship between two time series. Following the representation by Diks and Panchenko (2006, p. 1649-1657), let a strictly bivariate process $\left\{\left(X_{t}, Y_{t}\right)\right\}$, and $\left\{X_{t}\right\}$ Granger causes $\left\{Y_{t}\right\}$ if current and past values of variable $X$ contain information on

\footnotetext{
8 All variables are in logarithmic form.

9 See Stern (1993, 2000) and Apergis and Payne (2009)

${ }^{10}$ However, it must be noted that the TY test can suffer some loss of power since intentionally over-fits VAR models.
} 


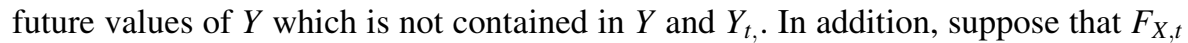
and $F_{Y, t}$ represent for time $t$ the information sets of past observations of $X_{t}$, and $Y_{t}$, respectively. Then, for a stationary bivariate time series process $\left\{\left(X_{t}, Y_{t}\right)\right\}, t \in \mathbb{Z}$, , we can represent formally that $\left\{X_{t}\right\}$ does not Granger causes $\left\{Y_{t}\right\}$ as

$$
\left(Y_{t+1, \ldots,} Y_{t+k}\right)\left|\left(F_{X, t}, F_{Y, t}\right) \sim\left(Y_{t+1, \ldots,} Y_{t+k}\right)\right| F_{Y, t} .
$$

Equation (3) represents the nonlinear Granger-causality test, where ' ' indicates equality in distributions and $k \geq 1 .^{11}$ Then, by following Hiemstra and Jones (1994), we can define the null hypothesis of Granger non-causality as: $H_{0}:\left\{X_{t}\right\}$ is not Granger causing $\left\{Y_{t},\right\}$. Under the null hypothesis, $Y_{t+1}$ is conditionally independent of $X_{t}, X_{t-1}, \ldots$, given $Y_{t}, Y_{t-1}, \ldots$ For finite lags $l_{X}$ and $l_{Y}$, the conditional independence can be tested as

$$
Y_{t+1}\left|\left(X_{t}^{l_{X}}, Y_{t}^{l_{Y}}\right) \sim Y_{t+1}\right| Y_{t}^{l_{Y}}
$$

where $X_{t}^{l_{X}}=\left(X_{t-l_{X+1}}, \ldots, X_{t}\right)$ and $Y_{t}^{l_{Y}}=\left(Y_{t-l_{Y+1}}, \ldots, Y_{t}\right)$. According to Diks and Panchenko (2006), Eq. (4) represents a statement about the invariant distribution of the $l_{X}+l_{y}+1$-dimensional vector $W_{t}=\left(X_{t}^{l_{X}}, Y_{t}^{l_{Y}}, Z_{t}\right)$, where $Z_{t}=Y_{t+1}$. By dropping the time index and assume that $l_{X}=l_{y}=1$, we can write $W=(X, Y, Z)$ as a random vector with invariant distribution of $\left(X_{t}^{l_{X}}, Y_{t}^{l_{Y}}, Y_{t+1}\right)$. Under the null the conditional distribution of $Z$ given, $(X, Y)=(x, y)$ is the same as $Z$ given $Y=y$. Therefore, we can restructure (4) by taking into account the joint probability density functions $f_{X, Y, Z}(x, y, z)$, where its marginals should satisfy the following relationship:

$$
\frac{f_{X, Y, Z}(x, y, z)}{f_{y}(y)}=\frac{f_{X, Y}(x, y)}{f_{Y}(y)} \frac{f_{Y, Z}(y, z)}{f_{Y}(y)}
$$

suggesting that $X$ and $Z$ are independent when $Y=y$ for each fixed value of $y$. Diks and Panchenko (2006) proved that the restated null hypothesis suggests that

$$
q=E\left[f_{X, Y, Z}(X, Y, Z) f_{Y}(Y)-f_{X, Y}(X, Y) f_{Y, Z}(Y, Z)\right] .
$$

By denoting the local density estimators of a $d_{w}$ variate random vector $W$ as $\hat{f}_{W}\left(W_{i}\right)=\frac{\left(2_{\varepsilon}\right)^{-d_{W}}}{n-1} \sum_{j, j \neq 1} I_{i j}^{W} I_{i j}^{W}=I\left(W_{i}-W_{j}<\varepsilon\right) .,{ }^{12}$ the test statistic can be presented as

$$
T_{n}(\varepsilon)=\frac{(n-1)}{n(n-2)} \sum_{i}\left(\hat{f}_{X, Y, Z}\left(X_{i}, Y_{i}, Z_{i}\right) \hat{f}_{Y}\left(Y_{i}\right)-\hat{f}_{X, Y}\left(X_{i}, Y_{i}\right) \hat{f}_{Y, Z}\left(Y_{i}, Z_{i}\right)\right) .
$$

For a sequence of bandwidths $\varepsilon_{n}=C n^{-\beta}$ with $C>0$ and $\beta \in\left(\frac{1}{4}, \frac{1}{3}\right)$, the statistic in (7) satisfies

$$
\sqrt{n} \frac{\left(T_{n}\left(\varepsilon_{n}\right)-q\right)}{S_{n}} \stackrel{d}{\rightarrow} N(0,1)
$$

\footnotetext{
11 Most of the times $k$ is equal to 1 .

12 where $I_{i j}^{W}=I\left(\left\|W_{i}-W_{j}\right\|<\varepsilon\right)$
} 
where $\stackrel{d}{\rightarrow}$ denotes convergence in distribution and $S_{n}$ is an estimator of the asymptotic variance of $T_{n}(\cdot)$. Finally, the test statistic in Eq. (7) for nonlinear causality is asymptotically distributed as standard normal and diverges to positive infinity under the alternative hypothesis. ${ }^{13}$ Before we estimate the nonlinear model, we must check if the nonlinearity assumption holds, and therefore, we utilize the BDS test (Brock et al. 1987). Under the null hypothesis, the BDS test implies that the variables under examination are identically and independently distributed (i.i.d.). However, under the alternative hypothesis, the test implies that they have linear or nonlinear dependency.

\section{The findings}

Examining for linear causality, the ADF and PP unit root and the KPSS stationary tests were employed to the intercept and trend (Table 3). The results from the ADF, PP, and KPSS statistics suggest that the variables are integrated of order one $I(1)$. Furthermore, we apply the Zivot and Andrews test (Table 4) for structural breaks. The result of that test also indicate that all the series are I(1). Accordingly, all variables are integrated of order one $I(1)$.

The Jarque-Bera (JB) tests indicate that all residuals are normal distributed, whereas the Portmanteau test show that there is no serial correlation. Furthermore, the Arch tests show that there is no heteroscedasticity for all equations in our analysis. Finally, the CUSUM and CUSUMS of square tests could not verify a stability violation. ${ }^{14}$ In addition, the results of the Johansen cointegration test for the countries are reported in Table 5. The findings suggest that there is a cointegration vector among the variables. The null hypotheses of zero cointegrating vector $r=0$ as well as less than or equal to one cointegrating vector $r \leq 1$ is rejected at the $5 \%$ significance level for the trace and the maximum eigenvalue statistics. For robustness check, Table 5 also presents the results for $r \leq 2$. The findings suggest that the null hypothesis for $r \leq 2$ is rejected at the 1 and 5 significance level for the trace and the maximum eigenvalue statistics (except for the cases of Paraguay and Peru). The above empirical findings suggest that there is a stable long-run equilibrium relationship among the variables. To determine the optimal lag length, the Schwarz Bayesian information criterion (SBIC) used to select the lag length for our models with the initial lag length set at $k=1$ ( $k=4$ for two countries).

On the other hand, before we estimate the testing for nonlinear causality, we must check if the nonlinearity assumption holds, and therefore, we utilize the BDS test. Two are the main parameters to estimate when applying the BDS test, namely, the embedding dimension $m$ and the distance $\varepsilon$. To obtain reliable results, we use a range of dimensions from 2 to 5. Table 6 presents the results of BDS test. It is clear from the statistics in Table 6 that the BDS test and the null of i.i.d is rejected for all

\footnotetext{
13 For more details please see Diks and Panchenko (2006).

14 Due to length limitations and the quantity of the results/tests performed, the results of the above diagnostic test cannot be presented. However, all the results are available upon request.
} 
Table 3 Results from the unit root tests

\begin{tabular}{|c|c|c|c|c|c|c|}
\hline & \multicolumn{2}{|l|}{ ADF test } & \multicolumn{2}{|l|}{ Perron test } & \multicolumn{2}{|c|}{ KPSS test } \\
\hline & Level & 1st diff. & Level & 1st diff. & Level & 1st diff. \\
\hline \multicolumn{7}{|l|}{ Argentina } \\
\hline $\operatorname{lnGDP}$ & $-3.44 * *$ & $-6.29 * * *$ & $-49.94 * * *$ & $-61.99 * * *$ & $0.09 *$ & $0.03^{*}$ \\
\hline lnMGDP & -1.99 & $-4.04 * * *$ & -9.21 & $-56.21 * * *$ & $1.61 * * *$ & $0.09 *$ \\
\hline $\operatorname{lnINV}$ & -2.83 & $-4.59 * * *$ & -14.57 & $-41.87 * * *$ & $1.17 * * *$ & $0.04 *$ \\
\hline \multicolumn{7}{|l|}{ Bolivia } \\
\hline $\operatorname{lnGDP}$ & -2.67 & $-5.22 * * *$ & $-39.87 * * *$ & $-54.57 * * *$ & $0.27 *$ & $0.05^{*}$ \\
\hline lnMGDP & $-3.73 * *$ & $-4.26^{* * *}$ & -12.6 & $-57.69 * * *$ & $0.36^{*}$ & $0.14^{*}$ \\
\hline $\operatorname{lnINV}$ & -2.90 & $-4.16^{* * *}$ & $-22.48 * *$ & $-51.28 * * *$ & $0.19^{*}$ & $0.04^{*}$ \\
\hline \multicolumn{7}{|l|}{ Brazil } \\
\hline lnGDP & $-3.40 *$ & $-5.53 * * *$ & $-47.26 * * *$ & $-61.69 * * *$ & $0.88 * * *$ & $0.04 *$ \\
\hline $\operatorname{lnMGDP}$ & -2.20 & $-4.09 * * *$ & -12.88 & $-52.19 * * *$ & $0.67 * * *$ & $0.04 *$ \\
\hline $\operatorname{lnINV}$ & -2.51 & $-4.44 * * *$ & $-19.53 * *$ & $-50.67 * * *$ & $0.33^{*}$ & $0.03^{*}$ \\
\hline \multicolumn{7}{|l|}{ Chile } \\
\hline lnGDP & -2.42 & $-5.85^{* * *}$ & $-57.49 * * *$ & $-73.27 * * *$ & $0.25^{*}$ & $0.03 *$ \\
\hline lnMGDP & -0.77 & $-3.59 * *$ & -3.36 & $-58.90 * * *$ & $1.52 * * *$ & $0.32 *$ \\
\hline $\operatorname{lnINV}$ & -2.91 & $-4.44 * * *$ & $-28.94 * * *$ & $-58.07 * * *$ & $1.14^{* * *}$ & $0.02^{*}$ \\
\hline \multicolumn{7}{|l|}{ Colombia } \\
\hline $\operatorname{lnGDP}$ & $-3.53 * *$ & $-5.56^{* * *}$ & $-43.34 * * *$ & $-69.29 * * *$ & $0.31^{*}$ & $0.02 *$ \\
\hline $\operatorname{lnMGDP}$ & -2.13 & $-3.68 * *$ & -9.49 & $-45.49 * * *$ & $0.96^{* * *} *$ & $0.05^{*}$ \\
\hline $\operatorname{lnINV}$ & $-3.50 * *$ & $-4.66^{* * *}$ & $-20.15 * * *$ & $-52.56 * * *$ & $0.43^{*}$ & $0.07 *$ \\
\hline \multicolumn{7}{|c|}{ Dominican Republic } \\
\hline $\operatorname{lnGDP}$ & $-4.32 * * *$ & $-5.55^{* * *}$ & $-43.48 * * *$ & $-58.19 * * *$ & $0.18 *$ & $0.02 *$ \\
\hline $\operatorname{lnMGDP}$ & -1.55 & $-3.22 *$ & -15.60 & $-48.56 * * *$ & $2.27 * * *$ & $0.04^{*}$ \\
\hline $\operatorname{lnINV}$ & -2.72 & $-4.47 * * *$ & $-18.24^{*}$ & $-57.87 * * *$ & $0.80 * * *$ & $0.05^{*}$ \\
\hline \multicolumn{7}{|l|}{ Ecuador } \\
\hline $\operatorname{lnGDP}$ & -2.94 & $-6.18 * * *$ & $-51.06 * * *$ & $-69.33 * * *$ & $0.12^{*}$ & $0.02 *$ \\
\hline $\operatorname{lnMGDP}$ & -2.42 & $-4.54 * * *$ & $-22.25^{* *}$ & $-62.01 * * *$ & $0.40^{*}$ & $0.07 *$ \\
\hline $\operatorname{lnINV}$ & $-4.01 * *$ & $-4.44 * * *$ & -16.47 & $-60.26 * * *$ & $0.94 * * *$ & $0.07 *$ \\
\hline \multicolumn{7}{|l|}{ El Salvador } \\
\hline $\operatorname{lnGDP}$ & $-3.44 *$ & $-3.72 * *$ & $-26.04 * * *$ & $-61.39 * * *$ & $0.43^{*}$ & $0.03 *$ \\
\hline $\operatorname{lnMGDP}$ & -1.52 & $-3.15^{*}$ & -3.43 & $-42.69 * * *$ & $0.53 * *$ & $0.25^{*}$ \\
\hline $\operatorname{lnINV}$ & -3.00 & $-3.28 *$ & -13.28 & $-45.24 * * *$ & $0.10^{*}$ & $0.05^{*}$ \\
\hline \multicolumn{7}{|l|}{ Guatemala } \\
\hline $\operatorname{lnGDP}$ & -2.45 & $-3.80 * *$ & -13.72 & $-55.08 * * *$ & $0.41 *$ & $0.14^{*}$ \\
\hline $\operatorname{lnMGDP}$ & $-3.94 * *$ & $-3.97 * *$ & -11.06 & $-50.77 * * *$ & $0.36^{*}$ & $0.06^{*}$ \\
\hline $\operatorname{lnINV}$ & -2.46 & $-4.01 * *$ & $-16.80^{*}$ & $-55.61 * * *$ & $0.25^{*}$ & $0.03^{*}$ \\
\hline \multicolumn{7}{|l|}{ Mexico } \\
\hline lnGDP & $-4.18 * * *$ & $-6.02 * * *$ & $-35.30 * * *$ & $-55.06^{* * * *}$ & $0.78 * * *$ & $0.01 *$ \\
\hline lnMGDP & $-3.59 * *$ & $-3.74 * *$ & $-20.25 * *$ & $-69.49 * * *$ & $0.25^{*}$ & $0.10^{*}$ \\
\hline $\operatorname{lnINV}$ & -2.89 & $-4.14 * * *$ & -15.64 & $-53.71 * * *$ & $0.44^{*}$ & $0.05^{*}$ \\
\hline
\end{tabular}


Table 3 continued

\begin{tabular}{|c|c|c|c|c|c|c|}
\hline & \multicolumn{2}{|l|}{ ADF test } & \multicolumn{2}{|l|}{ Perron test } & \multicolumn{2}{|c|}{ KPSS test } \\
\hline & Level & 1st diff. & Level & 1st diff. & Level & 1st diff. \\
\hline \multicolumn{7}{|l|}{ Paraguay } \\
\hline $\operatorname{lnGDP}$ & -1.90 & $-4.10 * *$ & $-44.72 * * *$ & $-66.01 * * *$ & $0.51^{* *}$ & $0.02 *$ \\
\hline lnMGDP & -2.40 & $-3.76 * *$ & -9.36 & $-81.82 * * *$ & $1.88 * * *$ & $0.12 *$ \\
\hline \multicolumn{7}{|l|}{ Peru } \\
\hline $\operatorname{lnGDP}$ & $-3.81 * *$ & $-5.75^{* * *}$ & $-42.69 * * *$ & $-60.86^{* * *}$ & $0.07 *$ & $0.02 *$ \\
\hline lnMGDP & -2.01 & $-3.61 * *$ & -12.68 & $-55.21 * * *$ & $1.98 * * *$ & $0.09 *$ \\
\hline $\operatorname{lnINV}$ & -2.39 & $-5.42 * * *$ & -11.35 & $-50.83 * * *$ & $0.81 * * *$ & $0.15^{*}$ \\
\hline \multicolumn{7}{|l|}{ Venezuela } \\
\hline $\operatorname{lnGDP}$ & -2.86 & $-4.18 * * *$ & $-62.20 * * *$ & $-77.58 * * *$ & $0.15^{*}$ & $0.02 *$ \\
\hline lnMGDP & $-3.88 * *$ & $-5.63 * * *$ & $-38.15 * * *$ & $-54.49 * * *$ & $1.98 * * *$ & $0.01^{*}$ \\
\hline $\operatorname{lnINV}$ & -2.39 & $-4.79 * * *$ & $-19.42 *$ & $-47.04 * * *$ & $0.32 *$ & $0.03 *$ \\
\hline
\end{tabular}

$* * *, * *$, and $*$ Significant at the 1,5 , and 10 levels, respectively

data. However, the results suggest that all countries are nonlinearly dependent, as well as that nonlinear causality testing is appropriate.

In the next step of the empirical investigation, we proceed to the estimation of nonlinear causality test (DP test), for our model following Bekiros and Diks (2008a, b). First, we apply the DP test in the raw data (pre-filtering step) to distinguish the nonlinear interrelationships, and second, we reapply it to the filtered VAR residuals to examine whether there is a strict nonlinear causality in nature or not. The value of bandwidth is set to one. ${ }^{15}$ Finally, the number of lags used for the nonlinear causality test is $l X=l Y=1$. The full results from both the linear and nonlinear causality tests are presented in Table 9 in the appendix. However, given the BDS results presented previously, we choose to summarize the findings from Table 9 only for those obtained when applying the nonlinear test. Specifically, Table 7 presents the findings on the nexus between military spending and growth rates when we applied the nonlinear causality tests for the raw data and for the residuals from the VAR specification. Similarly, Table 8 presents the findings on the relationship governing defence spending and gross capital formation. As a broad, general observation based on Table 7, it would appear that the dominant picture is that there is not any bidirectional relationship between military spending and the countries' growth rates. Furthermore, the nonlinear findings indicate unidirectional causality from the growth rates to military spending for the case of El Salvador and Paraguay. This tentatively can be interpreted that the growth of the economy allows more resources to be allocate to defence. The effective demand stimulative effect channel from defence spending to the economy seems to be indicating the majority of the causality findings for Argentina, Bolivia, Brazil,

\footnotetext{
15 Bandwidth values smaller (larger) than 1 result in larger (smaller) $p$ values (Bekiros and Diks $2008 \mathrm{a}, \mathrm{b})$.
} 
Table 4 Results from the ZA unit root tests with a structural break

\begin{tabular}{|c|c|c|c|c|c|}
\hline & Variable & Level & Break & 1st diff. & Break \\
\hline \multirow[t]{3}{*}{ Argentina } & $\operatorname{lnGDP}$ & $-7.67 * * *$ & 2009 & $-11.19 * * *$ & 1975 \\
\hline & lnMGDP & $-7.67 * * *$ & 2009 & $-11.19 * * *$ & 1975 \\
\hline & $\operatorname{lnINV}$ & -3.70 & 1981 & $-6.81 * * *$ & 1963 \\
\hline \multirow[t]{3}{*}{ Bolivia } & $\operatorname{lnGDP}$ & $-7.02 * * *$ & 1978 & $-11.05^{* * *}$ & 1970 \\
\hline & lnMGDP & $-5.99 * * *$ & 1975 & $-\mathrm{C} 10.61 * * *$ & 1976 \\
\hline & lnINV & -4.36 & 2003 & $-8.69 * * *$ & 2004 \\
\hline \multirow[t]{3}{*}{ Brazil } & $\operatorname{lnGDP}$ & $-6.57 * * *$ & 1977 & $-10.64 * * *$ & 2013 \\
\hline & lnMGDP & $-5.03 *$ & 1987 & $-8.88 * * *$ & 1981 \\
\hline & lnINV & -4.21 & 1995 & $-8.12 * * *$ & 1989 \\
\hline \multirow[t]{3}{*}{ Chile } & $\operatorname{lnGDP}$ & $-8.94 * * *$ & 1998 & $-14.02 * * *$ & 1965 \\
\hline & lnMGDP & $-5.36 * *$ & 1970 & $-9.56 * * *$ & 1969 \\
\hline & lnINV & $-5.54 * *$ & 1987 & $-9.90 * * *$ & 1983 \\
\hline \multirow[t]{3}{*}{ Colombia } & $\operatorname{lnGDP}$ & $-6.50 * * *$ & 1981 & $-11.72 * * *$ & 1998 \\
\hline & lnMGDP & $-5.03 *$ & 1972 & $-8.37 * * *$ & 1977 \\
\hline & $\operatorname{lnINV}$ & $-5.29 * *$ & 1999 & $-7.58 * * *$ & 1995 \\
\hline \multirow[t]{3}{*}{ Dominican Republic } & $\operatorname{lnGDP}$ & $-6.69 * * *$ & 2003 & $-10.24 * * *$ & 1970 \\
\hline & $\operatorname{lnMGDP}$ & -4.60 & 1987 & $-9.31 * * *$ & 1991 \\
\hline & $\operatorname{lnINV}$ & -4.75 & 1981 & $-9.36 * * *$ & 1964 \\
\hline \multirow[t]{3}{*}{ Ecuador } & $\operatorname{lnGDP}$ & $-8.16 * * *$ & 1982 & $-12.68 * * *$ & 1983 \\
\hline & $\operatorname{lnMGDP}$ & $-5.04 *$ & 1980 & $-9.64 * * *$ & 1984 \\
\hline & $\operatorname{lnINV}$ & $-6.49 * * *$ & 1965 & $-9.63 * * *$ & 1966 \\
\hline \multirow[t]{3}{*}{ El Salvador } & $\operatorname{lnGDP}$ & $-4.82 *$ & 1990 & $-10.54 * * *$ & 1986 \\
\hline & lnMGDP & -3.41 & 1979 & $-7.41 * * *$ & 1985 \\
\hline & lnINV & -4.38 & 1979 & $-7.07 * * *$ & 1978 \\
\hline \multirow[t]{3}{*}{ Guatemala } & $\operatorname{lnGDP}$ & $-9.82 * * *$ & 1992 & $-9.24 * * *$ & 1993 \\
\hline & lnMGDP & $-5.39 * *$ & 1992 & $-8.18 * * *$ & 1995 \\
\hline & $\operatorname{lnINV}$ & -4.49 & 2006 & $-8.49 * * *$ & 1975 \\
\hline \multirow[t]{3}{*}{ Mexico } & $\operatorname{lnGDP}$ & $-6.05 * * *$ & 2001 & $-9.50 * * *$ & 2002 \\
\hline & lnMGDP & $-4.83^{*}$ & 2004 & $-9.90 * * *$ & 2006 \\
\hline & $\operatorname{lnINV}$ & $-5.16 * * *$ & 1982 & $-8.16^{* * *}$ & 1995 \\
\hline \multirow[t]{2}{*}{ Paraguay } & $\operatorname{lnGDP}$ & $-8.34 * * *$ & 1998 & $-12.44 * * *$ & 2002 \\
\hline & lnMGDP & -3.45 & 2002 & $-13.59 * * *$ & 2005 \\
\hline \multirow[t]{3}{*}{ Peru } & $\operatorname{lnGDP}$ & $-6.56 * * *$ & 1979 & $-10.62 * * *$ & 1978 \\
\hline & lnMGDP & $-5.37 * *$ & 1975 & $-10.64 * * *$ & 2008 \\
\hline & $\operatorname{lnINV}$ & -3.54 & 1968 & $-7.42 * * *$ & 1982 \\
\hline \multirow[t]{3}{*}{ Venezuela } & $\operatorname{lnGDP}$ & $-8.28 * * *$ & 2002 & $-14.41 * * *$ & 1985 \\
\hline & lnMGDP & $-7.52 * * *$ & 2010 & $-10.66^{* * * *}$ & 2011 \\
\hline & $\operatorname{lnINV}$ & $-5.19 * *$ & 1983 & $-8.26 * * *$ & 1990 \\
\hline
\end{tabular}

Break denotes the time of the structure change

$* * *, * *$, and $*$ Significant at the 1,5 , and 10 levels, respectively 
Table 5 Results of Johansen's cointegration tests

\begin{tabular}{|c|c|c|c|c|c|c|}
\hline & \multicolumn{3}{|c|}{ Trace statistic $\left(\lambda_{\text {trace }}\right)$} & \multicolumn{3}{|c|}{ Maximum eigenvalue statistics $\left(\lambda_{\max }\right)$} \\
\hline & $r=0$ & $r \leq 1$ & $r \leq 2$ & $r=0$ & $r \leq 1$ & $r \leq 2$ \\
\hline Argentina & $47.93 * * *$ & $18.42^{* *}$ & $5.17 *$ & $32.51 * * *$ & $15.25 * *$ & $4.95^{*}$ \\
\hline Bolivia & $48.61 * * *$ & $27.30 * * *$ & $11.11 * *$ & $21.31 * *$ & $16.19 * *$ & $8.31 *$ \\
\hline Brazil & $36.08 * *$ & $18.19 * *$ & $5.30 *$ & $22.90 * *$ & $14.89 * *$ & $4.10^{*}$ \\
\hline Chile & $33.55 * *$ & $17.71 * *$ & $6.60 *$ & $21.83 * *$ & $14.91 * *$ & $5.02 *$ \\
\hline Colombia & $36.06^{* *}$ & $22.28 * *$ & $4.83 *$ & $23.78 * *$ & $18.45^{* *}$ & $3.15^{*}$ \\
\hline Dominican Republic & $49.15 * * *$ & $19.46^{* *}$ & $4.13 *$ & $29.69 * * *$ & $15.33 * *$ & $4.00 *$ \\
\hline Ecuador & $41.79 * * *$ & $17.84 * *$ & $5.41 *$ & $23.95 * *$ & $14.43 * *$ & $3.95 *$ \\
\hline El Salvador & $34.64 * *$ & $19.69 * *$ & $5.66^{*}$ & $24.94 * *$ & $17.09 * *$ & $4.91 *$ \\
\hline Guatemala & $72.53 * * *$ & $18.44^{* *}$ & $5.98 *$ & $56.09 * * *$ & $15.46^{* *}$ & $4.51 *$ \\
\hline Mexico & $38.76^{* * * *}$ & $20.78^{* *}$ & $6.77 * *$ & $22.98 * *$ & $15.01 * *$ & $5.20 *$ \\
\hline Paraguay & $19.02 * * *$ & $9.02 * *$ & $3.40 *$ & $18.01 * *$ & $9.02 * *$ & 2.10 \\
\hline Peru & $34.19 * *$ & $18.81 * *$ & $3.78 *$ & $23.38 * *$ & $15.02 * *$ & 2.01 \\
\hline Venezuela & $31.86^{* * *}$ & $18.63 * *$ & $5.04 *$ & $22.23 * *$ & $14.59 * *$ & $4.15^{*}$ \\
\hline
\end{tabular}

***, **, and * Significant at the 1,5 , and 10 levels, respectively, and $r$ is cointegration rank

Chile, Dominican Republic, and El Salvador, and Brazil, Mexico, and Venezuela and the nonlinear for Bolivia, Chile, and the Dominican Republic.

In broad generalization terms, the results on the bidirectional causality relationship between gross capital formation and military spending are also overall indicating the absence of strong nexus between the two variables. An exception can be observed only for the cases of Brazil and Peru in which a bidirectional nonlinear relationship is observed. A nonlinear causality running from gross capital formation to military spending is observed for the cases of Argentina, Brazil and Peru, whereas a nonlinear causality relationship from defence spending to gross capital formation in the cases of Brazil, Chile, Colombia, Peru, and Venezuela, respectively, may be tentatively interpreted as indicating effects from dual use infrastructure and technological spillovers.

\section{Concluding remarks}

A steadily growing body of empirical studies has addressed the subject of the economic effects of military spending with no unequivocal consensus emerging. SIPRI's new consistent database on defence expenditures, which extends the available time series covering in some cases the entire postwar period, presents the opportunity to (re)address the issue. This paper set out to examine via linear and nonlinear causality tests the nexus between defence spending, economic growth, and investment in the 13 Latin American countries for the period 1961-2014. The findings reported herein are not uniformed across all countries included in the sample. Both bidirectional, unidirectional and non-causality were empirically 
Table 6 BDS results

\begin{tabular}{|c|c|c|c|c|c|}
\hline & \multirow[t]{2}{*}{ Length in $\operatorname{SD}\left(\sigma^{2}\right)$} & \multirow{2}{*}{$\begin{array}{l}\text { Emdedding dimension } \\
(m)\end{array}$} & \multicolumn{3}{|c|}{ W statistic of variables } \\
\hline & & & $\operatorname{lnGDP}$ & lnMGDP & $\operatorname{lnINV}$ \\
\hline \multirow[t]{4}{*}{ Argentina } & 0.5 & 2 & $26.85 * * *$ & $49.77 * * *$ & $10.76 * * *$ \\
\hline & 0.5 & 3 & $40.16^{* * *}$ & $65.44 * * *$ & $9.93 * * *$ \\
\hline & 0.5 & 4 & $64.09 * * *$ & $61.97 * * *$ & $8.96 * * *$ \\
\hline & 0.5 & 5 & $69.38 * * *$ & $32.30 * * *$ & $8.28 * * *$ \\
\hline \multirow[t]{4}{*}{ Bolivia } & 0.5 & 2 & $3.51 * * *$ & $6.67 * * *$ & $2.80 * * *$ \\
\hline & 0.5 & 3 & $4.61 * * *$ & $7.32 * * *$ & $2.77 * * *$ \\
\hline & 0.5 & 4 & $6.41 * * *$ & $8.38 * * *$ & $2.38 * * *$ \\
\hline & 0.5 & 5 & $7.73 * * *$ & $8.63 * * *$ & $2.40 * * *$ \\
\hline \multirow[t]{4}{*}{ Brazil } & 0.5 & 2 & $5.59 * * *$ & $33.99 * * *$ & $21.48 * * *$ \\
\hline & 0.5 & 3 & $7.03^{* * *}$ & $22.98 * * *$ & $23.03 * * *$ \\
\hline & 0.5 & 4 & $4.09 * * *$ & $14.11 * * *$ & $30.89 * * *$ \\
\hline & 0.5 & 5 & $2.72 * * *$ & $16.47 * * *$ & $21.02 * * *$ \\
\hline \multirow[t]{4}{*}{ Chile } & 0.5 & 2 & $2.61 * * *$ & $28.13 * * *$ & $9.03 * * *$ \\
\hline & 0.5 & 3 & 0.34 & $45.92 * * *$ & $8.97 * * *$ \\
\hline & 0.5 & 4 & $4.89 * * *$ & $2.66 * * *$ & $5.25 * * *$ \\
\hline & 0.5 & 5 & $3.26 * * *$ & $1.74 * *$ & $3.51 * * *$ \\
\hline \multirow[t]{4}{*}{ Colombia } & 0.5 & 2 & $17.28 * * *$ & $24.51 * * *$ & $8.64 * * *$ \\
\hline & 0.5 & 3 & $21.33 * * *$ & $10.42 * * *$ & $1.96 * *$ \\
\hline & 0.5 & 4 & $20.53 * * *$ & $6.34 * * *$ & $5.40 * * *$ \\
\hline & 0.5 & 5 & $13.95 * * *$ & $4.41 * * *$ & $3.61 * * *$ \\
\hline \multirow[t]{4}{*}{ Dominican Republic } & 0.5 & 2 & $9.41 * * *$ & $16.30 * * *$ & $38.12 * * *$ \\
\hline & 0.5 & 3 & $77.17 * * *$ & $15.80 * * *$ & $31.57 * * *$ \\
\hline & 0.5 & 4 & $46.01 * * *$ & 1.19 & $7.26 * * *$ \\
\hline & 0.5 & 5 & $31.35 * * *$ & 0.74 & $4.88 * * *$ \\
\hline \multirow[t]{4}{*}{ Ecuador } & 0.5 & 2 & $5.29 * * *$ & $2.21 * * *$ & $10.36 * * *$ \\
\hline & 0.5 & 3 & $6.16^{* * *}$ & $4.53 * * *$ & $6.51 * * *$ \\
\hline & 0.5 & 4 & $12.26 * * *$ & $2.60 * * *$ & $15.14 * * *$ \\
\hline & 0.5 & 5 & $2.93 * * *$ & $1.70 *$ & $10.26 * * *$ \\
\hline \multirow[t]{4}{*}{ El Salvador } & 0.5 & 2 & $17.01 * * *$ & $21.37 * * *$ & $16.77 * * *$ \\
\hline & 0.5 & 3 & $11.88 * * *$ & $58.81 * * *$ & $56.65 * * *$ \\
\hline & 0.5 & 4 & $59.44 * * *$ & $58.27 * * *$ & $62.91 * * *$ \\
\hline & 0.5 & 5 & $10.93 * * *$ & $22.77 * * *$ & $59.56 * * *$ \\
\hline \multirow[t]{4}{*}{ Guatemala } & 0.5 & 2 & $36.04 * * *$ & $25.84 * * *$ & $14.63 * * *$ \\
\hline & 0.5 & 3 & $37.88 * * *$ & $37.45^{* * *}$ & $19.21 * * *$ \\
\hline & 0.5 & 4 & $68.29 * * *$ & $60.27 * * *$ & $26.28 * * *$ \\
\hline & 0.5 & 5 & $85.52^{* * * *}$ & $72.97 * * *$ & $38.56 * * *$ \\
\hline
\end{tabular}


Table 6 continued

\begin{tabular}{|c|c|c|c|c|c|}
\hline & \multirow[t]{2}{*}{ Length in $\mathrm{SD}\left(\sigma^{2)}\right.$} & \multirow{2}{*}{$\begin{array}{l}\text { Emdedding dimension } \\
(m)\end{array}$} & \multicolumn{3}{|c|}{ W statistic of variables } \\
\hline & & & $\operatorname{lnGDP}$ & $\operatorname{lnMGDP}$ & $\operatorname{lnINV}$ \\
\hline \multirow[t]{4}{*}{ Mexico } & 0.5 & 2 & $1.82 * *$ & $19.44 * * *$ & $13.25 * * *$ \\
\hline & 0.5 & 3 & $1.42 *$ & $17.56^{* * * *}$ & $4.52 * * *$ \\
\hline & 0.5 & 4 & $5.20 * * *$ & $17.75 * * *$ & $10.42 * * *$ \\
\hline & 0.5 & 5 & $3.47 * * *$ & $16.61 * * *$ & $3.74 * * *$ \\
\hline \multirow[t]{4}{*}{ Paraguay } & 0.5 & 2 & $10.24 * * *$ & $59.00 * * *$ & \\
\hline & 0.5 & 3 & $6.61 * * *$ & $22.74 * * *$ & \\
\hline & 0.5 & 4 & $40.09 * * *$ & $13.70 * * *$ & \\
\hline & 0.5 & 5 & $3.08 * * *$ & $9.44 * * *$ & \\
\hline \multirow[t]{4}{*}{ Peru } & 0.5 & 2 & $5.11 * * *$ & $32.95 * * *$ & $32.70 * * *$ \\
\hline & 0.5 & 3 & $16.79 * * *$ & $10.05 * * *$ & $44.60 * * *$ \\
\hline & 0.5 & 4 & $22.65 * * *$ & $6.12 * * *$ & $26.54 * * *$ \\
\hline & 0.5 & 5 & $15.55 * * *$ & $4.26 * * *$ & $18.05^{* * * *}$ \\
\hline \multirow[t]{4}{*}{ Venezuela } & 0.5 & 2 & $33.59 * * *$ & $13.22 * * *$ & $20.55 * * *$ \\
\hline & 0.5 & 3 & $92.57 * * *$ & $8.82 * * *$ & $14.91 * * *$ \\
\hline & 0.5 & 4 & $66.42 * * *$ & $5.16 * * *$ & $13.80 * * *$ \\
\hline & 0.5 & 5 & $45.29 * * *$ & $3.45 * * *$ & $9.35 * * *$ \\
\hline
\end{tabular}

$k$ represents five dimensions; SD equals 0.5

$* * *, * *$, and $*$ Significant at the 1,5 , and $10 \%$ levels, respectively

Table 7 Summary of the nonlinear findings on the nexus between military expenditures and growth

\begin{tabular}{|c|c|c|c|c|c|c|}
\hline & \multicolumn{2}{|c|}{ MGDP $\leftrightarrow$ GDP } & \multicolumn{2}{|c|}{ GDP $\rightarrow$ MGDP } & \multicolumn{2}{|c|}{ MGDP $\rightarrow$ GDP } \\
\hline & Raw Data & Resid. VAR & Raw Data & Resid. VAR & Raw Data & Resid. VAR \\
\hline Argentina & & & & & & + \\
\hline Bolivia & & & & & + & \\
\hline Brazil & & & & & & + \\
\hline Chile & & & & & + & \\
\hline \multicolumn{7}{|l|}{ Colombia } \\
\hline Dominican Republic & & & & & + & \\
\hline \multicolumn{7}{|l|}{ Ecuador } \\
\hline El Salvador & + & & + & & + & \\
\hline \multicolumn{7}{|l|}{ Guatemala } \\
\hline \multicolumn{7}{|l|}{ Mexico } \\
\hline Paraguay & & & + & & & \\
\hline \multicolumn{7}{|l|}{ Peru } \\
\hline Venezuela & & & & & & \\
\hline
\end{tabular}


Table 8 Summary of the nonlinear findings on the nexus between military expenditures and gross capital formation

\begin{tabular}{|c|c|c|c|c|c|c|}
\hline & \multicolumn{2}{|c|}{ MGDP $\leftrightarrow$ INV } & \multicolumn{2}{|c|}{$\mathrm{INV} \rightarrow \mathrm{MGDP}$} & \multicolumn{2}{|c|}{$\mathrm{MGDP} \rightarrow \mathrm{INV}$} \\
\hline & Raw Data & Resid. VAR & Raw Data & Resid. VAR & Raw Data & Resid. VAR \\
\hline Argentina & & & + & & & \\
\hline \multicolumn{7}{|l|}{ Bolivia } \\
\hline Brazil & & + & & + & & + \\
\hline Chile & & & & & + & \\
\hline Colombia & & & & & + & \\
\hline \multicolumn{7}{|c|}{ Dominican Republic } \\
\hline \multicolumn{7}{|l|}{ Ecuador } \\
\hline \multicolumn{7}{|l|}{ El Salvador } \\
\hline \multicolumn{7}{|l|}{ Guatemala } \\
\hline \multicolumn{7}{|l|}{ Mexico } \\
\hline \multicolumn{7}{|l|}{ Paraguay } \\
\hline Peru & & + & & + & & + \\
\hline Venezuela & & & & & + & \\
\hline
\end{tabular}

established. Yet, as a broad tentative generalization, the prevailing picture is that of a weak causal relationship. In most cases, no nexus could be statistically traced albeit, as noted, this is not a universally applicable inference. Clearly, the results presented above should be treated as a first reassessment of the issue at hand using the new consistent database constructed by SIPRI. Further empirical investigation is needed to examine both the determinants of such expenditures in Latin American countries as well as in order to probe further and in a more detailed manner into the economic effects of such government outlays.

Acknowledgements We would like to sincerely thank the Editor, Gonzalo Castañeda Gonzalo and an anonymous reviewer for their helpful and constructive comments on an earlier version of our manuscript and for spotting flaws and inconsistencies. Any remaining errors are solely the authors' responsibility.

Open Access This article is distributed under the terms of the Creative Commons Attribution 4.0 International License (http://creativecommons.org/licenses/by/4.0/), which permits unrestricted use, distribution, and reproduction in any medium, provided you give appropriate credit to the original author(s) and the source, provide a link to the Creative Commons license, and indicate if changes were made.

\section{Appendix}

See Table 9. 


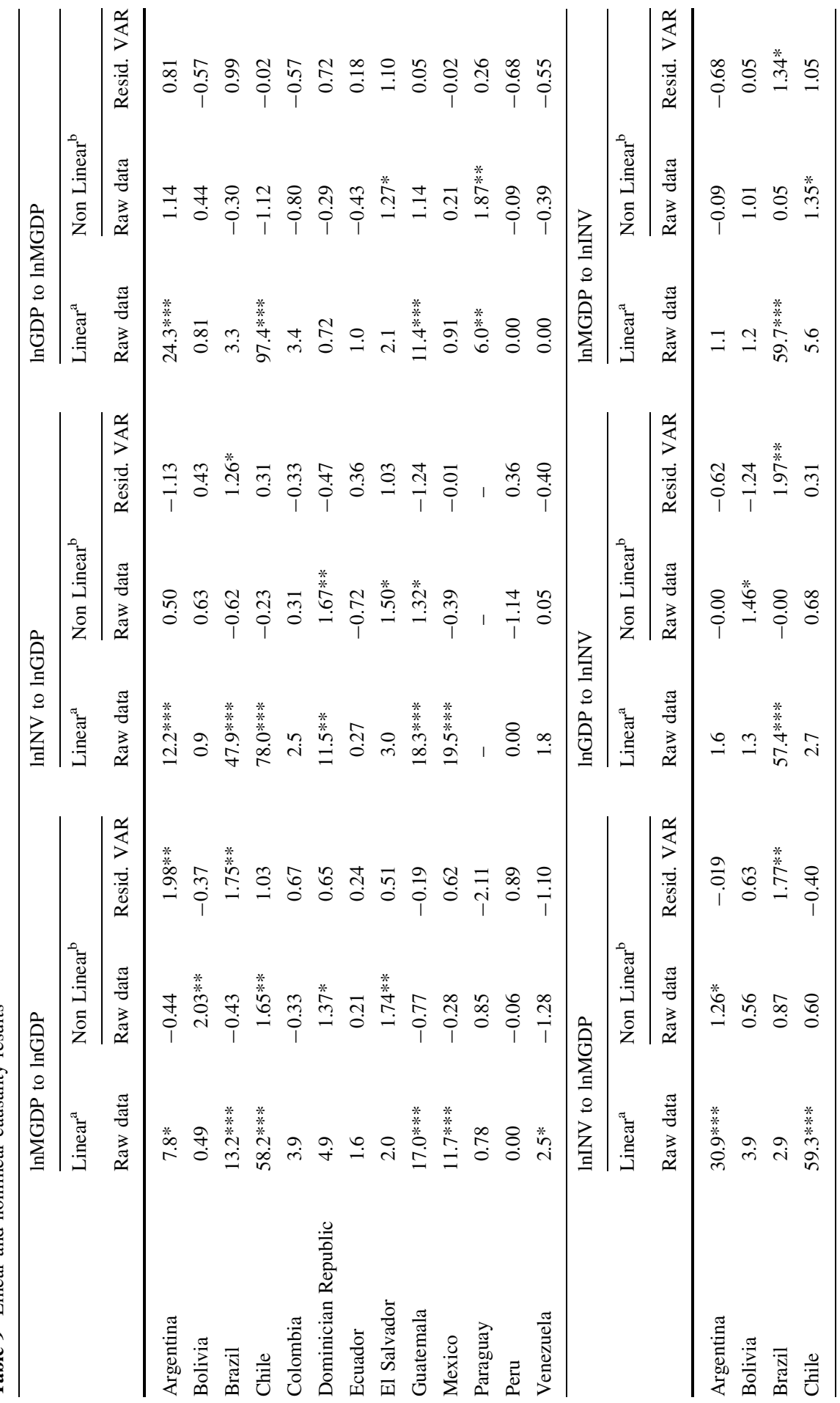




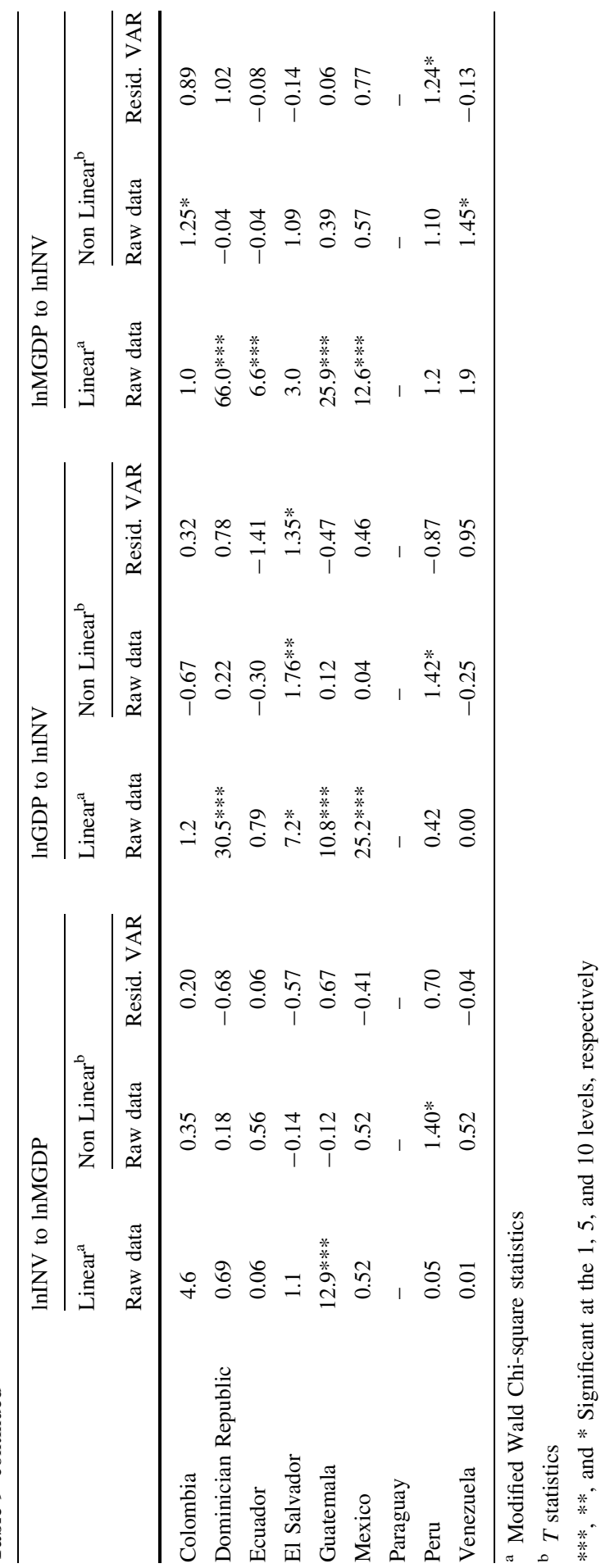




\section{References}

Alptekin A, Levine P (2012) Military expenditure and economic growth: a meta-analysis. Eur J Polit Econ 28:636-650

Apergis N, Payne JE (2009) Energy consumption and economic growth in Central America: evidence from a panel cointegration and error correction model. Energy Econ 31:211-216

Baek EG, Brock WA (1992) A nonparametric test for independence of a multivariate time series. Stat Sin 2:137-156

Bekiros SD, Diks CG (2008a) The relationship between crude oil spot and futures prices: cointegration, linear and nonlinear causality. Energy Econ 30(5):2673-2685

Bekiros SD, Diks CG (2008b) The nonlinear dynamic relationship of exchange rates: parametric and nonparametric causality testing. J Macroecon 30(4):1641-1650

Biglaiser G (2002) Guardians of the nation? Economists, generals, and economic reform in Latin America. University of Notre Dame Press, Notre Dame

Bove V, Brauner J (2016) The demand for military expenditure in authoritarian regimes. Def Peace Econ 27(5):609-625

Brock W (1991) Causality, chaos, explanation and prediction in economics and finance. In: Casti J, Karlqvist A (eds) Beyond belief randomness prediction and explanation in science. CRC Press, Boca Raton

Brock WA, Dechert WD, Scheinkman JA (1987) A test for independence based on the correlation dimension. Social Systems Research Institute, University of Wisconsin-Madison. Working Paper 8702

Caporale GM, Pittis N (1999) Efficient estimation of cointegrating vectors and testing for causality in vector autoregressions. J Econ Surv 13:3-35

Catoggio MS (2011) Religious beliefs and actors in the legitimation of military dictatorships in the Southern Cone, 1964-1989. Lat Am Perspect 38(6):25-37

Compton R, Paterson B (2016) Military spending and growth: the role of institutions. Def Peace Econ 27(3):301-322

Desli E, Gkoulgkoutsika A, Katrakilidis C (2016) Investigating the dynamic interaction between military spending and economic growth. Rev Dev Econ. doi:10.1111/rode.12268

Dickey DA, Fuller WA (1979) Distribution of the estimators for autoregressive time series with a unit root. J Am Stat Soc 75:427-431

Diks CGH, DeGoede J (2001) A general nonparametric bootstrap test for Granger causality. In: Broer HW, Krauskopf W, Vegter G (eds) Global analysis of dynamical systems. Institute of Physics Publishing, Bristol, pp 391-403

Diks C, Panchenko V (2006) A new statistic and practical guidelines for nonparametric Granger causality testing. J Econ Dyn Control 30(9):1647-1669

Dix R (1994) Military coups and military rule in Latin America. Armed Forces Soc 20(3):439-456

Drèze J (2006) Military expenditure and economic growth. In: Clark DE (ed) The Elgar companion to development studies. Edward Elgar, Cheltenham, pp 377-381

Dunne JP, Smith R (2010) Military expenditure and Granger causality: a critical review. Def Peace Econ 21(5-6):427-441

Dunne JP, Tian N (2013) Military expenditure and economic growth: a survey. Econ Peace Secur J $8(1): 5-11$

Dunne JP, Tian N (2015) Military expenditure, economic growth and heterogeneity. Def Peace Econ 26(1):15-31

Dunne JP, Tian N (2016) Military expenditure and economic growth, 1960-2014. Econ Peace Secur J 11(2):50-56

Dunne JP, Uye M (2010) Military spending and development. In: Tian A (ed) The global arms trade: a handbook. Routledge, London, pp 293-305

Dunne P, Perlo-Freeman S, Smith R (2008) The demand for military expenditure in developing countries: hostility vs capability. Def Peace Econ 19(4):293-302

Engle RF, Granger C (1987) Co-integration and error-correction: representation, estimation, and testing. Econometrica 55:251-276

Frantz E, Geddes B (2016) The legacy of dictatorship for democratic parties in Latin America. J Politics Lat Am 8(1):3-32 
Granger CWJ (1969) Investigating causal relation by econometric and cross-sectional method. Econometrica 37:424-438

Heo U, Ye M (2016) Defense spending and economic growth around the globe: the direct and indirect link. Int Interact 42(5):774-796

Hiemstra C, Jones JD (1994) Testing for linear and nonlinear Granger causality in the stock price-volume relation. J Financ 49(5):1639-1664

Hou N, Chen B (2013) Military expenditure and economic growth in developing countries: evidence from system GMM estimates. Def Peace Econ 24(3):183-193

Johansen S, Juselius K (1990) Maximum likelihood estimation and inference on cointegration with applications to the demand for money. Oxf Bull of Econ Stat 52(2):169-210

Kapetanios G (2005) Unit-root testing against the alternative hypothesis of up to $\mathrm{m}$ structural breaks. J Time Ser Anal 26(1):123-133

Klein T (2004) Military expenditure and economic growth: peru 1970-1996. Def Peace Econ 15(3):275-288

Kollias C, Paleologou SM (2016) Investment, growth, and defense expenditure in the EU15: revisiting the nexus using SIPRI's new consistent dataset. Econ Peace Secur J 11(2):27-36

Kuzozumi E, Yamamoto Y (2000) Modified lag augmented autoregressions. Econom Rev 19:207-231

Kwiatkowski D, Phillips PCB, Schmidt P, Shin Y (1992) Testing the null hypothesis of stationary against the alternative of a unit root. J Econom 54:159-178

Looney R, Frederiksen P (1988) Economic determinants of Latin American defence expenditures. Armed Forces Soc 14(4):459-471

Looney R, Frederiksen P (2000) The effect of declining military influence on defence budgets in Latin America. Armed Forces Soc 26(3):437-449

Malizard J (2015) Does military expenditure crowd out private investment? A disaggregated perspective for the case of France. Econ Model 46:44-52

Malizard J (2016) Military expenditure and economic growth in the European Union: evidence from SIPRI's extended dataset. Econ Peace Secur J 11(2):38-44

Menyah K, Wolde-Rufael Y (2010) $\mathrm{CO}_{2}$ emissions, nuclear energy, renewable energy and economic growth in the US. Energy Policy 38(6):2911-2915

Murdoch J, Pi C-R, Sandler T (1997) The impact of defence and non-defence public spending on growth in Asia and Latin America. Def Peace Econ 8(2):205-224

Norden D (1996) Redefining political-military relations in Latin America: issues of the new democratic era. Armed Forces Soc 22(3):419-440

Peláez A (2007) Defence spending and peacekeeping in Uruguay. Def Peace Econ 18(3):281-302

Perlo-Freeman S, Sköns E (2016) Snakes and ladders: the development and multiple reconstructions of the Stockholm International Peace Research Institute's military expenditure data. Econ Peace Secur J 11(2):5-13

Phillips PCB, Perron P (1988) Testing for a unit root in time series regressions. Biometrica 75:335-346

Ramos EM (2004) Country survey XIX: mexico. Def Peace Econ 15(1):83-99

Reitschuler G, Loening J (2005) Modeling the defence-growth nexus in Guatemala. World Dev 33(3):513-526

Scheetz T (1991) The macroeconomic impact of defence expenditures: some econometric evidence for Argentina, Chile, Paraguay and Peru. Def Econ 3(1):65-81

Sims CA, Stock JH, Watson M (1990) Interference in linear time series models with some unit roots. Econometrica 58:113-144

Smith R (2016) Military expenditure data: theoretical and empirical considerations. Def Peace Econ. doi:10.1080/10242694.2016.1245823

Stern DI (1993) Energy use and economic growth in the USA: a multivariate approach. Energy Econ $15: 137-150$

Stern DI (2000) A multivariate cointegration analysis of the role of energy in the US macroeconomy. Energy Econ 22:267-283

Stroup MD, Heckelman JC (2001) Size of the military sector and economic growth: A panel data analysis of Africa and Latin America. J Appl Econ 4:329-360

Toda HY, Yamamoto T (1995) Statistical Inference in vector autoregressions with possibly integrated process. J Econom 66:225-250

Vargas J (2012) The persistent Colombian conflict: subnational analysis of the duration of violence. Def Peace Econ 23(2):203-223 
Wang Y (2013) Determinants of Southeast Asian military spending in the post-cold war era: a dynamic panel analysis. Def Peace Econ 24(1):73-87

Wolde-Rufael Y (2004) Disaggregated industrial energy consumption and GDP: the case of Shanghai, 1952-1999. Energy Econ 26(1):69-75

Wolde-Rufael Y (2005) Energy demand and economic growth: the African experience. J Policy Model 27:891-903

Wolde-Rufael Y (2006) Electricity consumption and economic growth: a time series experience for 17 African countries. Energy Policy 34(10):1106-1114

Zivot E, Andrews D (1992) Further evidence of great crash, the oil price shock and unit root hypothesis. J Bus Econ Stat 10:251-270 